\title{
Sea level and temperature variations from a tide and waves gauge recording at Wallis Islands, during the recent pause of global warming
}

\section{Thierry HOIBIAN ${ }^{1}$, Michel ALLENBACH ${ }^{1}$, Enelio LIUFAU ${ }^{2}$, Karine BRUNET ${ }^{2}$, Atoloto MALAU ${ }^{2}$, Falalika TUHIMUTU-TAOFFIFENUA ${ }^{2}$}

\section{Université de la Nouvelle-Calédonie - BP R4 98851 Nouméa Cedex,}

Nouvelle-Calédonie.hoibian.thierry@univ-nc.nc ; senv@mail.wf

2. Service Territorial de l'Environnement des iles Wallis et Futuna - BP 294,

Mata'Utu - 98600 - Uvéa, Wallis \& Futuna.

Abstract: a SEABIRD, temperature, tide and waves gauge SBE26+, has been immersed for nearly three years, between 2010 and 2012, near Wallis islands, at an average depth of 35 meters. Results concerning the temperature and sea level variation during this periods [2010 - 2012] are compared to meteorological data and others oceanic recordings from international ocean monitoring organization. All shown a significant decrease of the sea surface temperature (SST) and a rise of the mean sea level (MSL). This cooling episode is related to long lasting La Nina episodes, which dominated the period.

\section{Key words:}

Tides, Waves \& temperature gauge, SBE26+, Sea level rise (ADT), Sea surface temperature (SST), Global warming.

Résumé : Une sonde de température, de marée et de vagues SEABIRD, SBE26 +, a été immergée pendant près de trois ans, entre 2010 et 2012, près des îles Wallis, à une profondeur moyenne de 35 mètres. Les résultats concernant la variation de la température et du niveau de la mer au cours de cette période [2010-2012] sont comparés aux données météorologiques et à d'autres enregistrements océaniques des organisations internationales de surveillance des océans. Tous ont montré une diminution significative de la température de surface de l'océan (SST) et une remontée du niveau moyen de la mer (MSL-ADT). Cet épisode de refroidissement est lié à une succession d'épisodes La Nina, de longue durée qui dominent la période.

\section{Mots-clés :}

Sonde de marée, de vagues et de température, SBE26+, Montée du niveau de la mer, ADT, Température océanique en surface, SST, Réchauffement climatique. 


\section{Thème 7 - Risques côtiers}

\section{Introduction}

Wallis islands are located in the South-West Pacific between Fidji islands and American Samoa islands (figure 1). It's a huge volcano rising more than $2000 \mathrm{~m}$ over seafloor, but land relief is quite reduced with culminating point at mount Lulu, with an altitude of $150 \mathrm{~m}$. The main island extends about $15 \mathrm{~km}$ in the North to South direction and $7 \mathrm{~km}$ in the east west direction. It is surrounded by a lagoon of 3 to $5 \mathrm{~km}$ width.

\section{Regional settings:}

Concerning the oceanic environment Wallis islands are located below the equator, by $13^{\circ} 02^{\prime}$ Lat South in the western pacific gyre (figure 1), (FIEUX, 2010).

Regional meteorological environment is strongly linked to the variations of the ITCZ (Inter Tropical Convergence Zone) that determine the type of weather (BEUCHER, 2010). Meteorological climate is dominated by two seasons the warm season, from November to April, warm and rainy which is also the "hurricane season" and the "winter season", from May to October, a little less warm and rainy (BELL et al., 2012, CHUNG \& POWER, 2015).

Standard winds conditions are dominated by south-east trades Winds that blows most of the year, and stronger during summer season than in winter. The intensity of the Walker cell trade winds is the main factor in the great tropical ocean events, El Niño and La Nina. Rarely some westerly conditions may occur. Hurricanes are less frequent than in the more southern zone of the tropical Pacific with a return time of about 3 years.

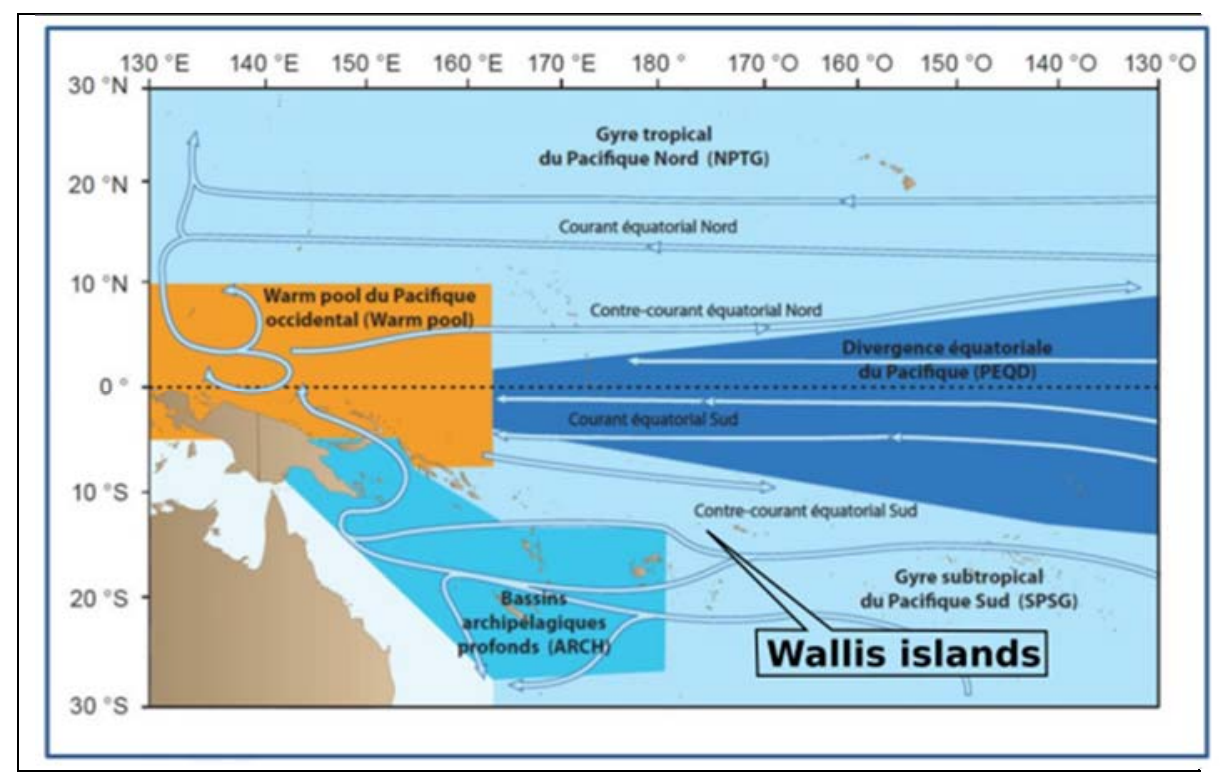

Figure 1. Oceanic circulation in the South-West Pacific. (in GANACHAUD et al. 2011). 


\section{XVèmes Journées Nationales Génie Côtier - Génie Civil \\ La Rochelle, 29 au 31 mai 2018}

\section{El Nino - La Nina :}

Among the regional oceanological phenomena, El Nino and la Nina episodes are the most important. They have a strong influence on the regional climate of the tropical and equatorial Pacific, on both sides of the basin, from Latin America to Australia and Indonesia.

Figure 2 and 3 below show the considerable variations in temperature anomaly (SST) between the warm El Nino event and the cooler La Nina events.

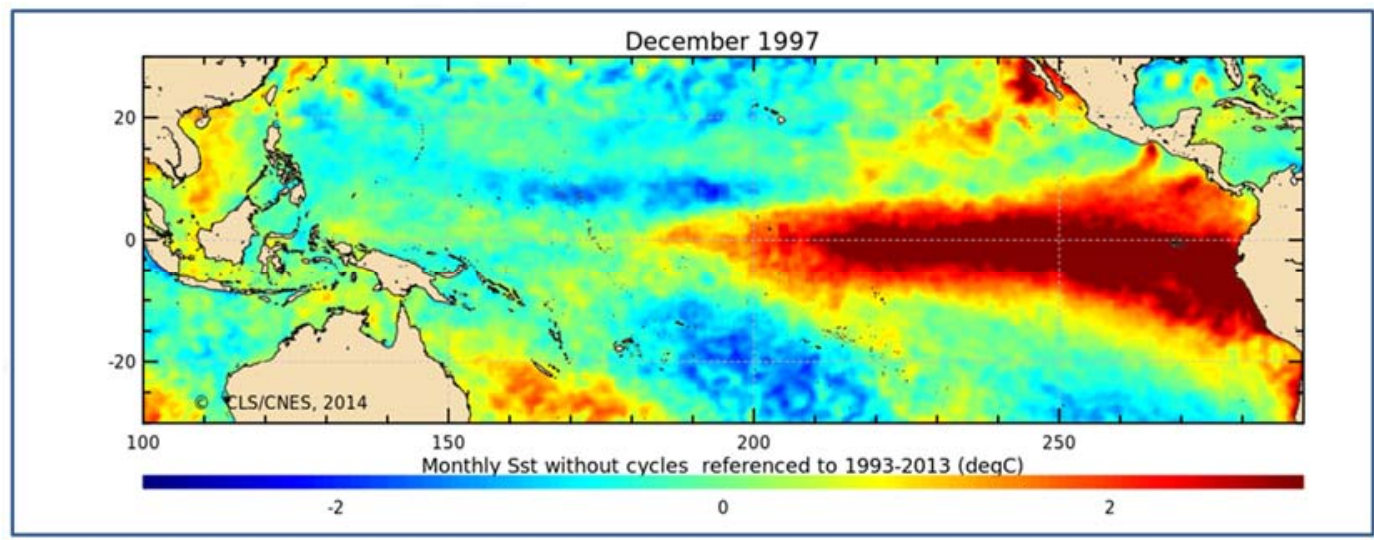

Figure 2. Monthly Sea Surface Temperature (SST) map of the equatorial pacific during a strong El Niño event, in December 1997 (CLS, CNES, 2014).

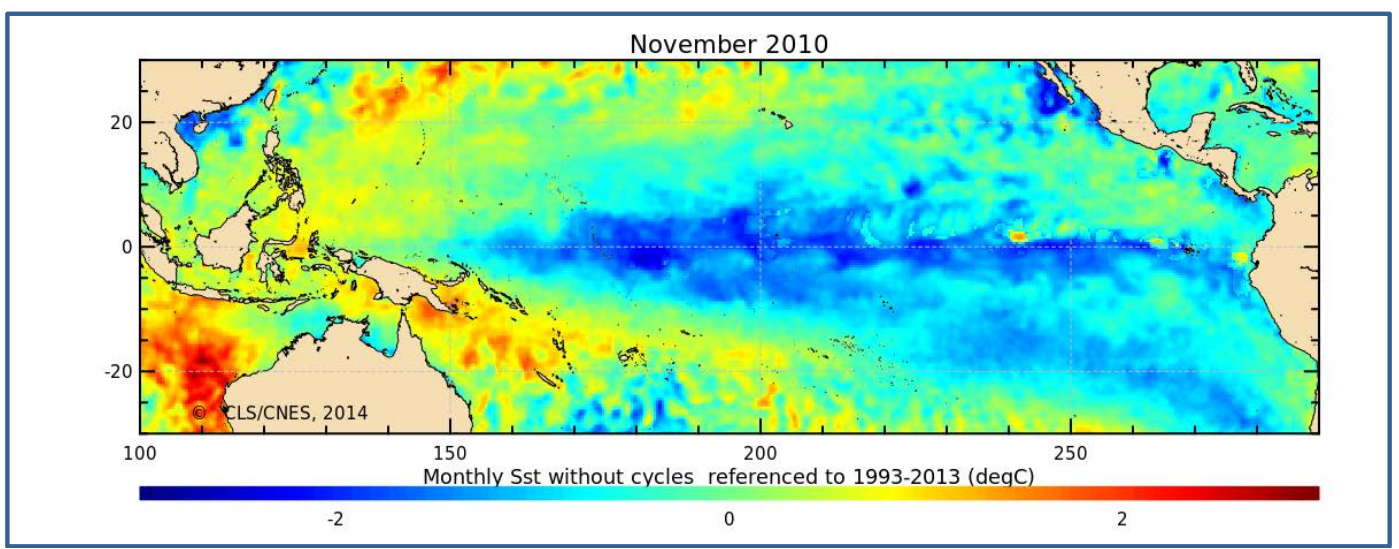

Figure 3. Monthly Sea Surface Temperature (SST) anomaly map of the equatorial pacific during a La Nina event, in November 2010 (CLS, CNES, 2014).

The gauge:

A temperature, tide and waves gauge, SEABIRD SBE26+, belonging to the CRIOBE (Frenh Polynesia), has been immersed for nearly three years, between 2010 and 2012, on a cradle anchored to the bottom of the sea, at an average depth of 35 meters.

Location was on the south western slope, off the barrier reef of Wallis Islands, near Avatolu inlet (figure 4). [Latitude $13^{\circ} 16^{\prime}$ South - longitude $176^{\circ} 16^{\prime}$ West]. Duration of 


\section{Thème 7 - Risques côtiers}

the session was about 28 months and the sampling rate was fixed at 15 minute. We present some results concerning mainly the sea water temperatures and the sea level variations occurring during this period.

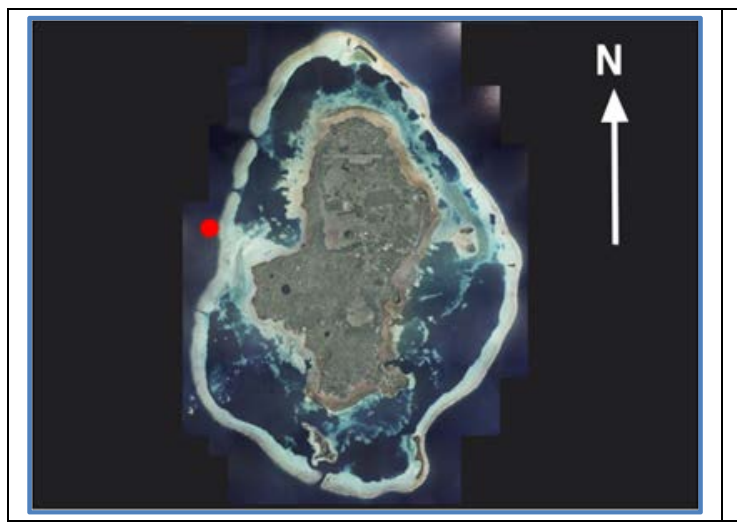

Figure 4. Location of the SBE26+ gauge at Wallis islands.

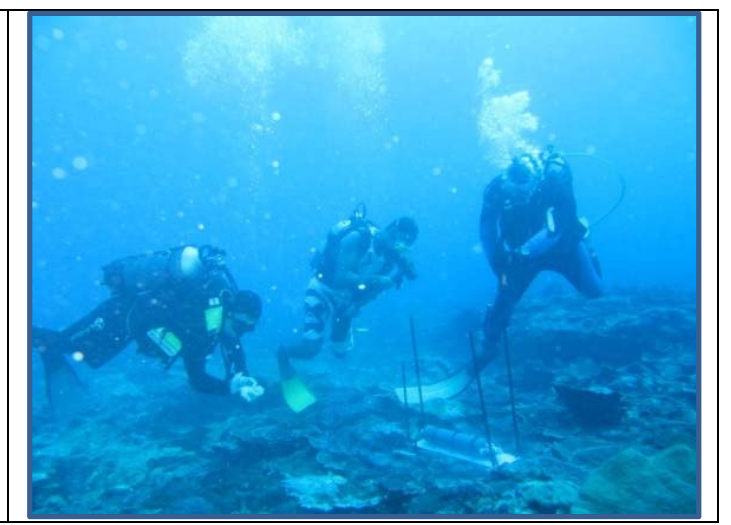

Figure 5. Installation of the SBE26+gauche on the sea bottom.

\section{Results}

\subsection{Analysis of the temperature recording}

Raw recordings of the sea water temperature for about 83.468 values, show great variations, but also some global trends (figure 6). These data needed to be filtered to compute daily and monthly averages. The results are plotted as curves and boxplot to highlight trends in seawater temperature variations (figure 7).

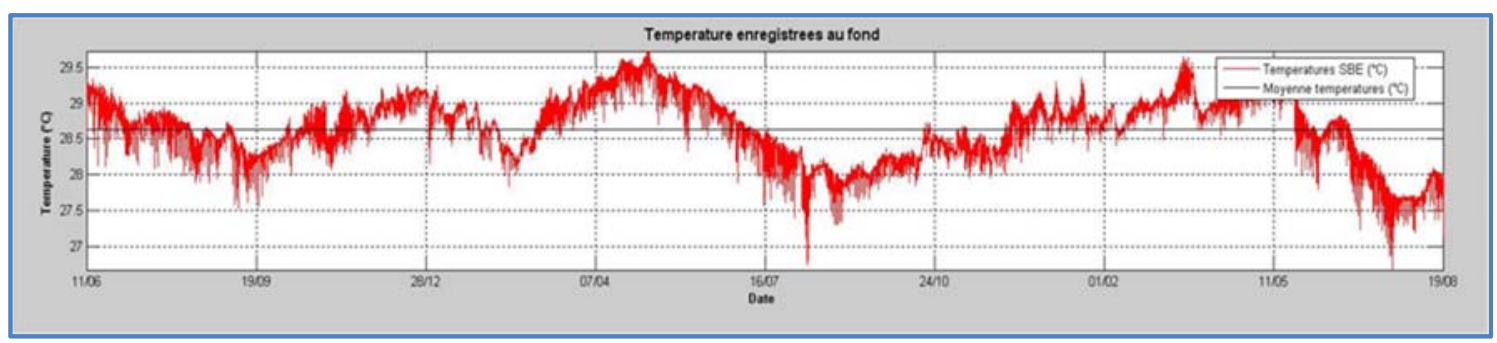

Figure 6. Raw recording of the sea water temperature at the bottom.

All the graphs clearly show a downward trend of the decrease of temperatures over the nearly three years studied.

\subsection{Comparison with meteorological data}

Comparison of monthly averaged air temperatures from Hihifo airport meteorological station, (figure 8) indicates also a decrease of about $-0.25^{\circ} \mathrm{C}$ to $-0.50{ }^{\circ} \mathrm{C}$ between each year, and a maximum difference of $-0.93{ }^{\circ} \mathrm{C}$ for the two years. An average difference of 


\section{XVèmes Journées Nationales Génie Côtier - Génie Civil \\ La Rochelle, 29 au 31 mai 2018}

$-0.63{ }^{\circ} \mathrm{C}$ was observed for the months common between 2010 and 2012 . This attests the veracity of the phenomenon of a significant decrease of the temperature of the atmosphere.

Same comparison has been made with the recordings of the SST from the Copernicus (CMEMS) server which shows a strong relation.

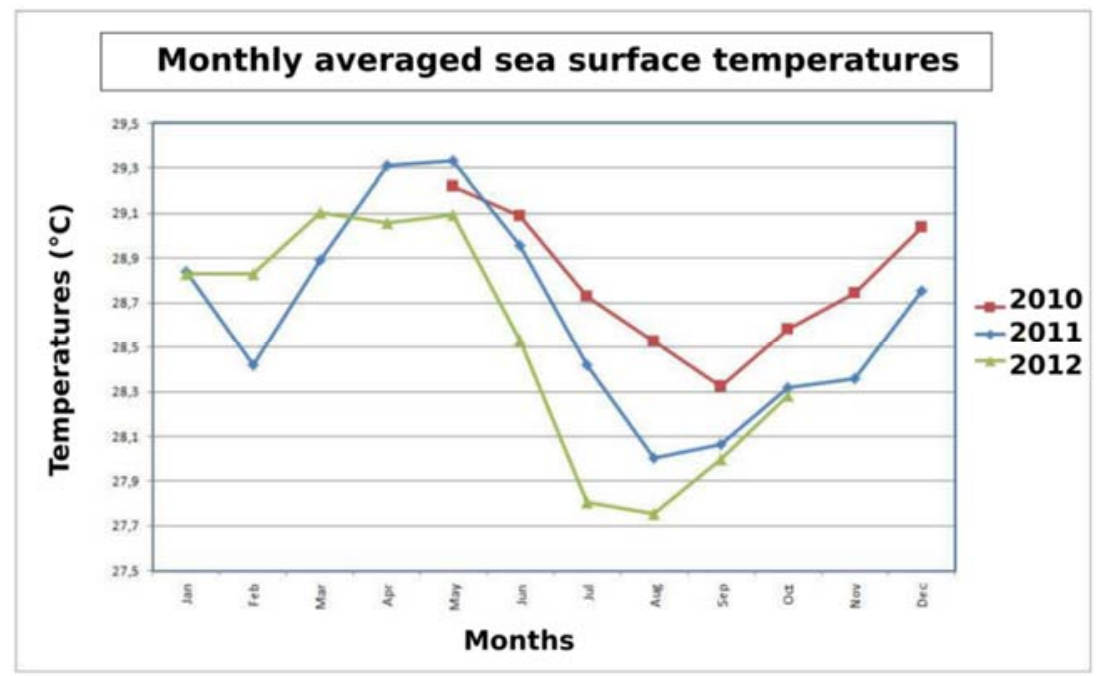

Figure 7: Superposition of the monthly averaged seawater temperatures from the SBE $26+$, gauge.

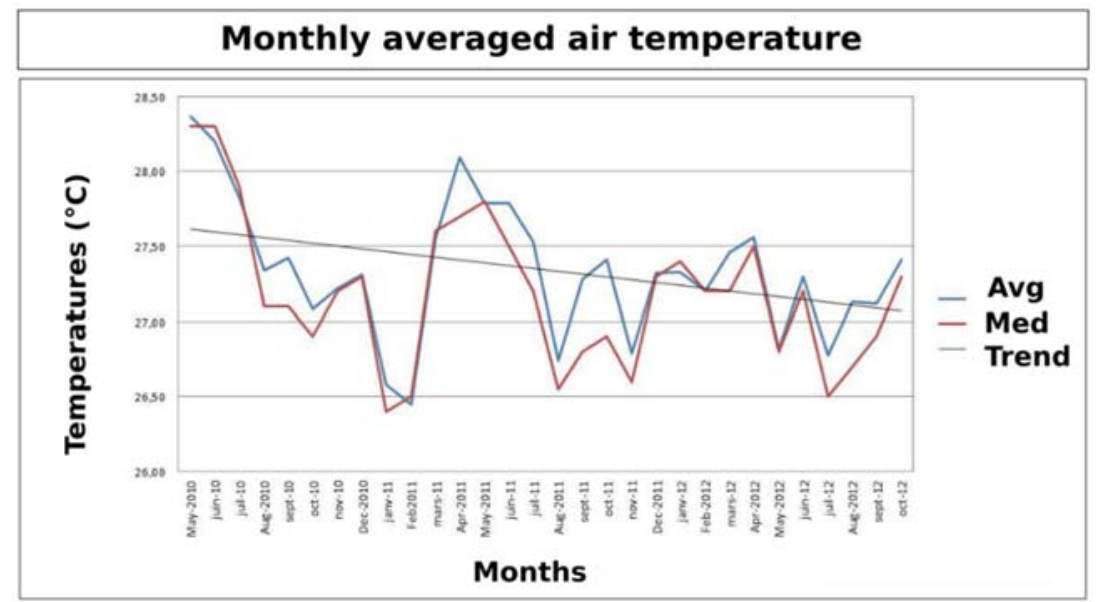

Figure 8: Monthly averaged, median and trend of air temperatures at Hihifo airport meteorological station.

\subsection{Sea level variations : MSL - ADT}

Same processing have been applied to the raw data of hydrostatic pressure of the tide gauge, converted to seal level using fitting routine to get daily averaged data of the sea level. The resulting data have been compared to the recording of the Absolute Dynamic 


\section{Thème 7 - Risques côtiers}

Topography delivered by the Aviso Oceanobs Las server (las.aviso.oceanobs.com/las/UI.vm) and Copernicus websites, as netCDF files.

Results showed a good correspondence with the ADT variations, down to the centimeter level. Some exceptions may be observed for local events probably bounded to the eddies of the equatorial gyre.

Fitted curves let us distinguish three stages (figure 9 below):

- a first period from November 2010 to April 2011, with an increasing elevation trend,

- a second period with a stable sea level trend and a great variability, from April 2011 to May 2012

- a last period, with also a stable sea level trend but a week variability, from May 2012 to August 2012.

This show a slight increase of the sea level due to the reestablishment of the Walker circulation at the west of the basin, after a short El Nino event. On a wider period, the curve of the rate of the sea level rise shows a noticeable decrease in the in the center of the basin (Nino3-4 area) (see figure 12 below).

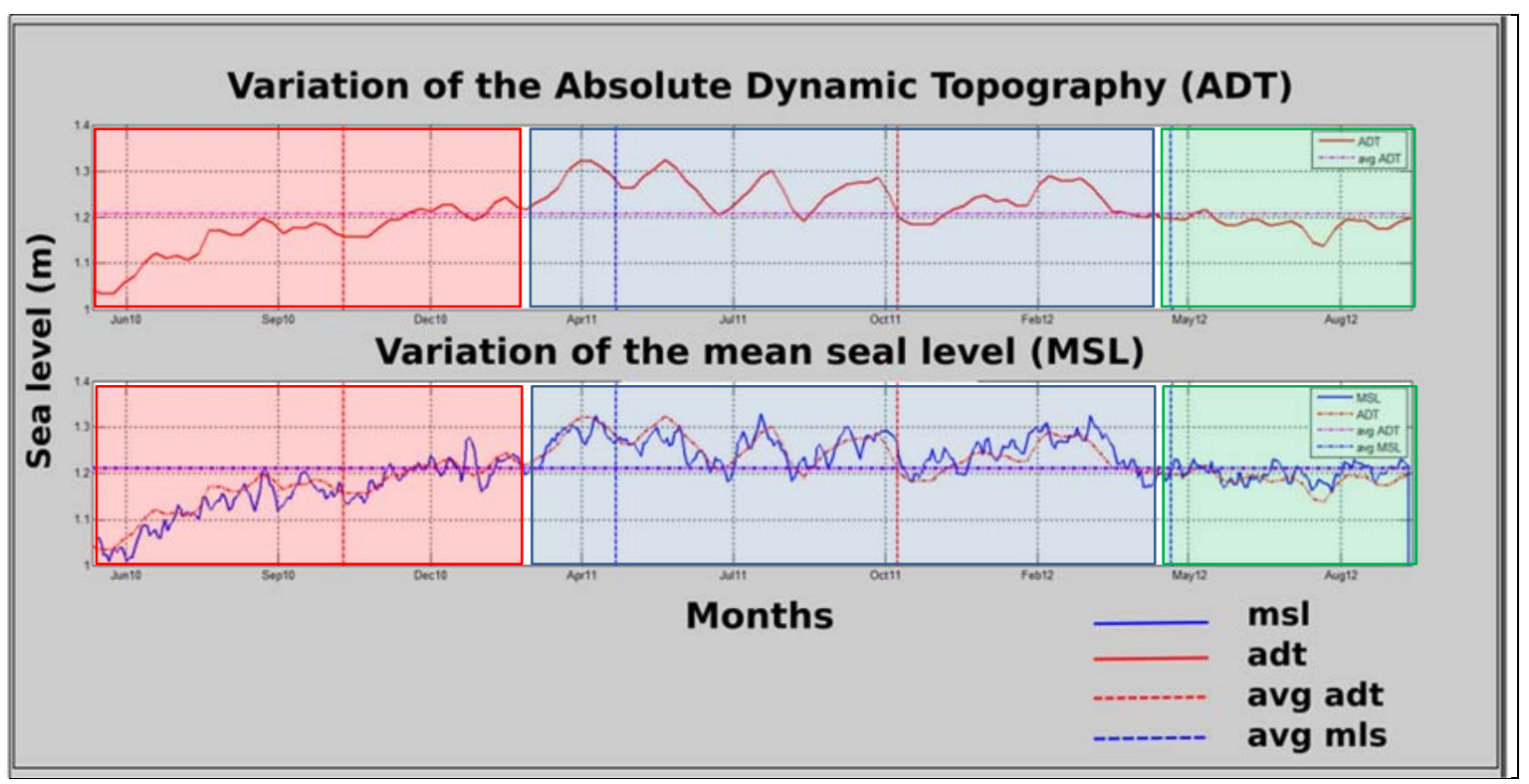

Figure 9. Fitted curves of the MSL time series since November 2010 to August 2012

The relationship between local sea level variations (MSL) and the circulation of equatorial oceanic water masses is found in Walker's circulation, which causes widespread migration of East Pacific waters to the opposite side of the ocean. This leads to a lowering of the sea level towards the east of the basin and a rise at the west end as well as an accumulation of warm water in the Warm Pool. Recent observations show an accumulation of these warm waters into the deep, down to $700 \mathrm{~m}$ (CMEMS, 2016) 


\section{XVèmes Journées Nationales Génie Côtier - Génie Civil \\ La Rochelle, 29 au 31 mai 2018}

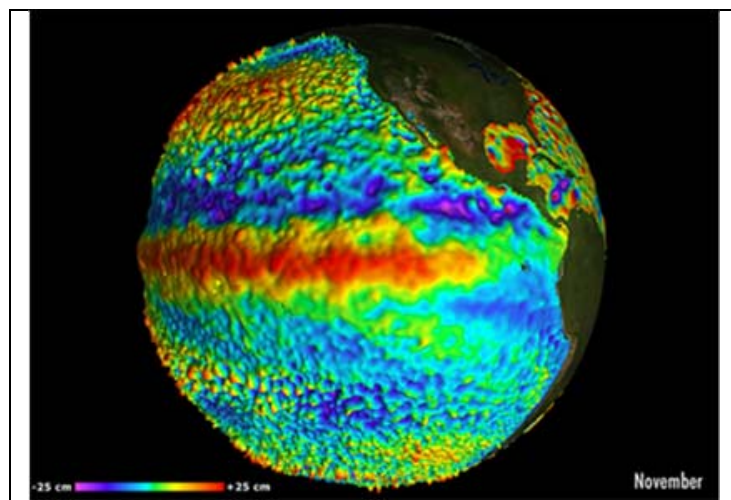

Figure 10. Sea height anomaly map during a weak El Nino event (CMEMS).

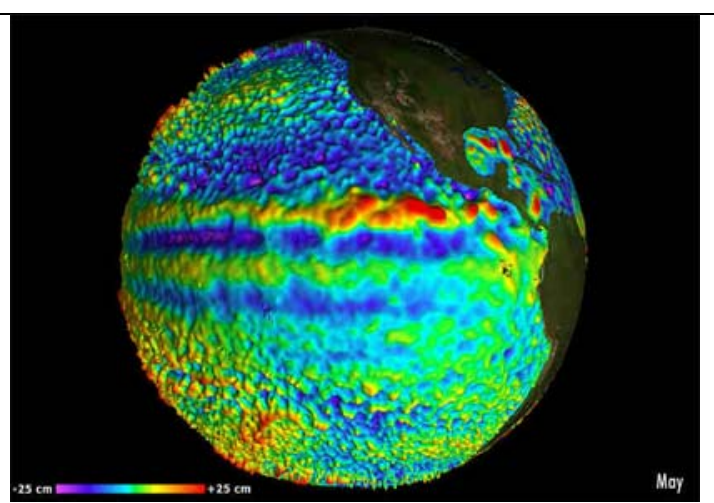

Figure 11. Sea height anomaly map during a La Nina event (CMEMS).

\section{Conclusions}

From CMEMS Service Helpdesk it can be said ; "Despite the Global Mean Sea Level at a $3.0 \mathrm{~mm} / \mathrm{yr}$ rate since 1993, there have been significant deviations from this rate in the past: for example in 1993-1996 after the Pinatubo eruption, and in 2007-2011 with the drops caused by a long lasting La Nina events". This can be seen on the time series of Sea Level Anomalies since 1993 (figure 12 below).

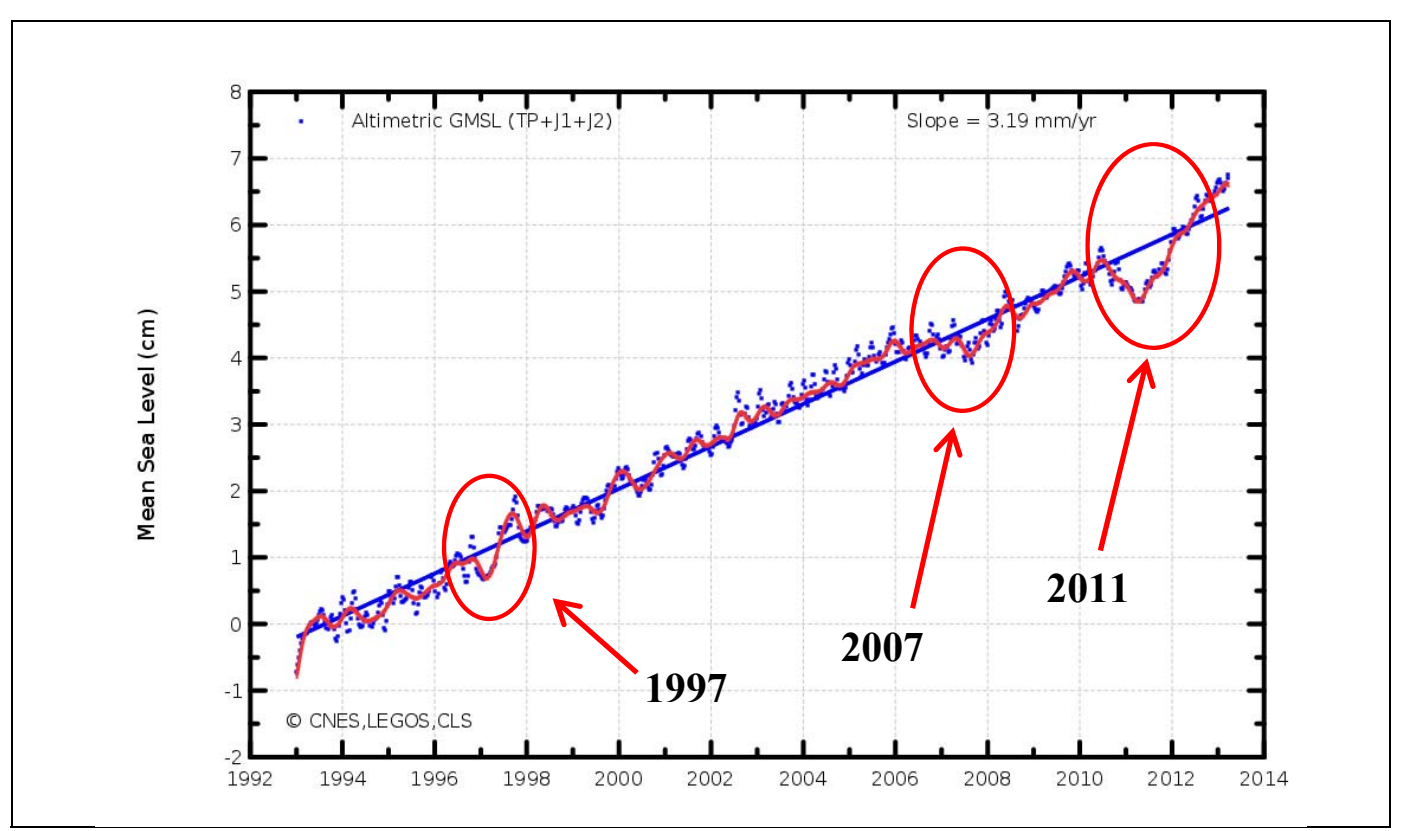

Figure 12. Anomalies in the rate of the seal level increase since 1992 to 2014, for the global ocean. (CNES, LEGOS, CLS).

This figure also reveals that, if the 1997 El Niño was exceptionally strong, the following La Nina lasted longer. Concerning the Nino index, in spite of two strong El Niño's 


\section{Thème 7 - Risques côtiers}

(1997-1998 and 2015-2016), there is have been a predominance of La Nina conditions during this period (CMEMS, 2016).

The conclusions is that what had been called a "pause in the global warming" was corresponding to a conjunction of climatic events occurring during this period such as; emissions of volcanic ashes in the atmosphere, long lasting La Nina events and a decrease in solar activity. It also seems that some of the warm waters masses have been stored into the mid-depth at the western part of the basin (CAZENAVE, 2014 ; MASSON DELMOTTE, 2015).

\section{Acknowledgements:}

Special acknowledgement is due to "Veronique" at CMEMS Help Service Desk for her explanation about the lowering of the rate of the sea level rise and the recent storage of ocean heat into the depth, to Alexandre GANACHAUD for his explanations about oceanic circulation in this area and also to the CRIOBE for having let us analyze the data of their SBE6+ marine gauge.

\section{References}

CMEMS (2016). The Copernicus Marin Environment Monitoring - Service Ocean State Report. Journal of Journal of Operational Oceanography. Taylor \& Francis group.

BELL J.D., JOHNSON J.E. , GANACHAUD A.S., GEHRKE P.C., HOBDAY A.J., HOEGH-GULDBERG O., LE BORGNE R., LEHODEY P., LOUGH J.M., PICKERING T., PRATCHETT M.S., WAYCOTT M. (2012). Vulnérabilité des ressources halieutiques et aquacoles du Pacifique tropical face au changement climatique : Résumé à l'intention de la Polynésie française, de la Nouvelle-Calédonie et de Wallis et Futuna. South Pacific Commission. Nouméa.

BEUCHER F. (2010). Manuel de météorologie tropicale. (C) Météo France.

CAZENAVE A., H-B DIENG, MEYSSIGNA, B., VON SCHUMANN K., DECHARME, B., BERHIER, E. (2014). The rate of sea level rise. Nature Climate Change Letter, Vol. 4, pp 358-361. https://doi.org/10.1038/NCLIMATE2159

CHUNG C.T.Y., POWER S.B. (2015). Modelled Rainfall Response to Strong El Niño Sea Surface - Temperature Anomalies in the Tropical Pacific. Center for Australian Weather and Climate Research, Bureau of Meteorology, Melbourne, Victoria, Australia. FIEUX M. (2010). L'Océan planétaire. Collection les cours, Ecole nationale des Techniques avancées Paris. Les presses de l'ENSTA.

GANACHAUD A., GUPTA A.S., ORR J.C., WIJFFELS S.E., RIDGWAY K.R. HEMER M.A., MAES C., CRAIG. (2011). Observed and expected changes to the tropical Pacific Ocean. Chapter 3, in BELL \& al..

MASSON, DELMOTTE, V., (2015). Comment le réchauffement climatique dérègle la machine climatique. Journal Le Monde du 08 octobre 2015. 